\title{
SPECIES DIVERSITY AND DISTRIBUTION PATTERN OF GRASSLAND AND CULTIVATED LAND SPECIES IN UPPER MANANG, NEPAL TRANS-HIMALAYAS
}

\author{
Kuber Prasad Bhatta* and Ram Prasad Chaudhary* \\ *Central Department of Botany, Tribhuvan University, Kirtipur, Nepal.
}

\begin{abstract}
One of the easiest and the most common way to estimate the biological diversity at a place is to enumerate the organisms at species level, which helps to find the basic patterns of biodiversity at the place. A sound knowledge on floristic composition of particular area is essential to understand the resources, their sustainable use and conservation purposes. Altogether 600 specimens were collected from the Upper Manang area covering an elevation gradient of 2600m to 5200m from sea level, and of which 220 species belonging to 138 genera and 50 families were identified up to species level and used to estimate species richness. Of the total identified species, greatest diversity was found within the families Compositae and Labiatae, comprising 14 and 11 genera, respectively. Similarly, the greatest species diversity was found within the genera Potentilla (12 species) and Primula (6 species). Second order polynomial regression showed unimodal pattern of species richness along elevation gradient, showing greatest species richness between $3500 \mathrm{~m}$ to $4000 \mathrm{~m}$ altitude, whereas no any angiosperm species was encountered beyond 5100m.
\end{abstract}

Key words: Species diversity; Grassland; Cultivated land; Manang.

\section{INTRODUCTION}

Biological diversity encompasses all levels of natural variation within the living organisms from the molecular and genetic levels to the species and ecosystem level and we are interacting with different levels of biodiversity in various ways due to such variations. Sound knowledge on floristic composition of particular area is essential to understand the plant resources, their sustainable use and conservation purposes. Beyond the species level, biological diversity includes definite patterns, processes and components upto landscape level; however the components are being interdependent with each other (Huston, 1998). One of the easiest and probably the most common way to estimate the biological diversity at a place is to enumerate the organisms at species level, which helps to find the basic patterns of biodiversity - "how many species are there?" and "what is the composition and distribution of the species found at that place?” (Cox \& Moore, 2005). Flora is a simple kind of biodiversity exploration that attempts to estimate and helps to find out the basic patterns of biodiversity at a particular place.

Although botanical exploration in Nepal was started in the beginning of $19^{\text {th }}$ century by Buchanan Hamilton in 1802, being a remote area very few works have been carried out in the floral diversity of Upper Manang. So, preparation of inventory of plant species from such an unexplored area helps to create awareness about plant resources and will show the need of conservation for their sustainable management. Upper Manang area is highly rich in medicinal plants (Bhattarai et al., 2006). A database with description of such plants will really support the alleviation of poverty of peoples of that area (Pohle, 1990). Present study is mainly aimed to collect and identify the species of angiosperms and gymnosperms from the grasslands and cultivated lands of Upper Manang at least up to species level and to find out distribution pattern (regional and altitudinal) and uses of the plants identified.

\section{STUDY AREA}

Manang district lies in the extreme northern side of Gandaki zone in the north-central part of Nepal, with an area of $2246 \mathrm{sq}$ $\mathrm{km}$ at $28^{\circ} 27^{\prime}-28^{\circ} 54^{\prime} \mathrm{N}$ latitudes and 83 $50^{\circ}-84^{\circ} 34^{\prime} \mathrm{E}$ longitudes within Annapurna conservation area. The district is the part of trans-Himalayan zone of Nepal having semi-arid type of climate and physiographiy. Almost $83.56 \%$ of the total area is occupied by mountain and hill. Forest and shrubs cover only $4.58 \%$ of total area whereas pasture and lake \& river cover $10.92 \%$ and $0.29 \%$, respectively. The cultivated land covers only $0.65 \%$ of total land (Pohle, 1990).

Author for Correspondence: Ram Prasad Chaudhary, Central Department of Botany, Tribhuvan University, Kirtipur, Nepal. E-mail: ram@cdbtu.wlink.com.np. 


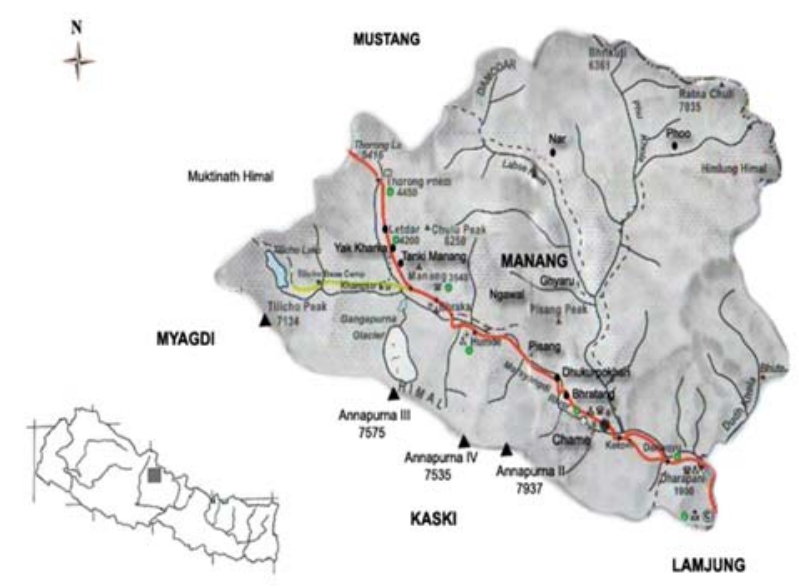

Fig1: Map showing VDCs of Manang District (Source: Pohle, 1990)

The Upper Manang mainly includes the Nar-Phoo valley and Nyeshang valley, which lies to the north and north-west of Manang district occupying about 2/3 of total territory of district. Upper Manang consists of 9 Village Development Committees of the district (Fig1).

\section{MATERIALS AND METHODS}

Plants specimens from grasslands and cultivated lands of Upper Manang area were collected by expedition organized by the Central Department of Botany, Tribhuvan University, Kirtipur under the Norwegian Council for Higher Education's Program for Development Research and Education (NUFU) funded project from June 2004 to September 2004. For each probable species, 2 to 3 specimens were collected with appropriate field notes. Herbarium specimens were prepared and managed using techniques of Forman and Bridson (1989). The herbarium specimens are stored in Tribhuvan University Central Herbarium (TUCH).

Preliminary identification of collected plant specimens was done with the help of experts of Tribhuvan University and National Herbarium and Plant Laboratories, Godawari (KATH) and then confirmed by using relevant literatures such as: Grierson and Long (1983-2001), Noltie (1994, 2000), Polunin and Stainton (1984), Zhengyi and Raven (1996-2001), etc. Distribution range for each species was determined with the help of field notes and the herbarium specimens from the same place stored at TUCH by previous workers. However, an average altitude for each species was considered for the analysis of species richness. Multiple linear regression analysis was used to find out the trend of species richness along elevation gradient.

\section{RESULTS}

Altogether 600 specimens were collected from the study area covering an elevation gradient of $2600 \mathrm{~m}$ to $5200 \mathrm{~m}$ from sea level, and of which 220 species belonging to 138 genera and 50 families were identified upto species level. Of the total identified species, 2 species of gymnosperms belong to 2 genera and 2 families, and 218 species of angiosperms belong to 136 genera and 48 families (Table1). Among them, greatest species diversity was found within the families Compositae and
Labiatae, comprising 14 and 11 genera, respectively. Similarly, the greatest species diversity was found within the genera Potentilla (12 species) and Primula (6 species) (Table1). Out of total identified species, 37 species were reported from within or near the agricultural field as weed, of which 29 species were found to be growing along the margins of cultivated lands as well as in nearby grasslands, and rest of the species were found to be restricted only to the grassland. The most common weeds were Equisetum debile, Avena fatua, Phleum alpinum, Trisetum spicatum, Sonchus wightianus, Cicerbita macrorhiza var. saxitilis, Calendula officinalis, Artemisia gmelinii, Artemisia campbellii, Lamium amplexicaule, Elsholtzia eriostachya, Elsholtzia densa, Rumex nepalensis, Fagopyrum esculantum, Heracleum candicans, Arabidopsis himalaica, Cannabis sativa, Scutellaria prostata, Veronica biloba, Descurainia sophia, Chenopodium album, Trigonella emodi, Medicago falcata, Argyrolobium roseum, Arisaema jaquemontii, Impatiens sulcata,, Canvolvulus arvensis, Malva verticillata, Geranium pratense, etc.

Species richness pattern along an elevation gradient was analysed by multiple linear regression technique. At first, simple linear regression was applied for the analysis, which was found to be insignificant $(p=0.44)$. Second order polynomial regression showed considerable improvement over previous one $(p=0.004)$, showing the hump-shaped pattern of species richness along elevation gradient, showing greatest species richness between $3500 \mathrm{~m}$ to $4000 \mathrm{~m}$ altitude, where as no any angiosperm species was encountered beyond 5100m (Fig 2). On the other hand, very little change in species richness was observed between 3500 and 4000masl. On the basis of the information published in Press et al. (2000), we analyzed and found that 114 species are reported occurring throughout Nepal; 65 species only in West and Central Nepal, 20 species in Central and East Nepal; and 23 species only in Central Nepal.

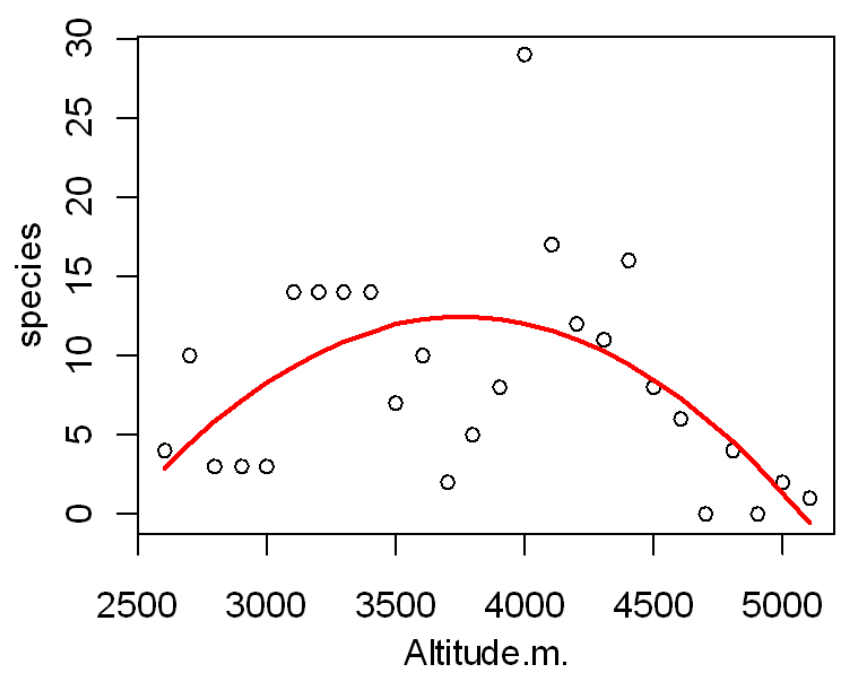

Fig 2: Regression line showing hump-shaped pattern of species richness

Most of the recorded species are found to be economically important. Altogether 85 species were found to be having medicinal values. Among them, some species have highly potential value in medicine like Neopicrorhiza 
Table1: List of recorded families, genera and species

\begin{tabular}{|c|c|c|c|c|c|c|c|}
\hline S. No. & Family & Genera & Species & S.No. & Family & Genus & Species \\
\hline 1 & Araceae & 1 & 1 & 26 & Juncaceae & 1 & - \\
\hline 2 & Balsaminaceae & 1 & 1 & 27 & Labiatae & 11 & 15 \\
\hline 3 & Berberidaceae & 1 & 1 & 28 & Leguminosae & 10 & 13 \\
\hline 4 & Boraginaceae & 4 & 4 & 29 & Lentibulariaceae & 1 & 1 \\
\hline 5 & Brassicacaeae & 10 & 12 & 30 & Liliaceae & 4 & 5 \\
\hline 6 & Campanulaceae & 1 & 2 & 31 & Malvaceae & 1 & 1 \\
\hline 7 & Cannabaceae & 1 & 1 & 32 & Onagraceae & 1 & 2 \\
\hline 8 & Caprifoliaceae & 1 & 2 & 33 & Orchidaceae & 3 & 3 \\
\hline 9 & Caryophyllaceae & 1 & 1 & 34 & Orobranchaceae & 1 & 1 \\
\hline 10 & Chenopodiaceae & 1 & 1 & 35 & Papaveraceae & 2 & 3 \\
\hline 11 & Compositae & 14 & 32 & 36 & Parnassiaceae & 1 & 1 \\
\hline 12 & Convolvulaceae & 1 & 1 & 37 & Plantaginaceae & 1 & 1 \\
\hline 13 & Crassulaceae & 2 & 5 & 38 & Polygalaceae & 1 & 1 \\
\hline 14 & Cupressaceae & 1 & 1 & 39 & Polygonaceae & 8 & 11 \\
\hline 15 & Cyperaceae & 1 & 1 & 40 & Primulaceae & 2 & 9 \\
\hline 16 & Dipsacaceae & 2 & 2 & 41 & Ranunculaceae & 6 & 11 \\
\hline 17 & Elaeagnaceae & 1 & 1 & 42 & Rosaceae & 5 & 15 \\
\hline 18 & Ephedraceae & 1 & 1 & 43 & Rubiaceae & 1 & 2 \\
\hline 19 & Ericaceae & 2 & 3 & 44 & Santalaceae & 1 & 1 \\
\hline 20 & Euphorbiaceae & 1 & 1 & 45 & Saxifragaceae & 1 & 5 \\
\hline 21 & Fumariaceae & 2 & 3 & 46 & Scrophulariaceae & 7 & 12 \\
\hline 22 & Gentianaceae & 4 & 8 & 47 & Solanaceae & 2 & 2 \\
\hline 23 & Geraniaceae & 1 & 5 & 48 & Umbelliferae & 3 & 5 \\
\hline 24 & Gramineae & 6 & 6 & 49 & Urticaceae & 1 & 1 \\
\hline 25 & Iridaceae & 1 & 1 & 50 & Valerianaceae & 1 & 1 \\
\hline
\end{tabular}

scrophulariiflora, Dactylorhiza hatagiera, Nardostachys grandiflora, Ephedra gerardiana, Aconitum naviculare, Delphinium brunonianum, Origanum vulgare, Elsholtzia eriostachya, Polygonatum hookeri, etc (Bhattarai et al. 2006). Similarly, 18 species are used for food or its ingredient. Some examples include rhizome of Arisaema jaquemontii is boiled for making curry; leaves of Fagopyrum esculentum used as vegetable as well as seeds are floured to make bread; fruits of Cotoneaster affinis are eaten. Similarly, highly nutritious juice is extracted from fruits of Hippophae tibetana. Some species are extremely poisonous, such as Physochlaina praealta, Hyoscyamus niger, Bistorta affinis, Stipa species, etc of which Physochlaina praealta and Stipa species are dried and then used as fodder in winter. Some other species are found strongly attached with their myths such as Thymus linearis, Cassiope fastigiata, Tanacetum gracile, whose scent by burning are supposed to be effective to get rid of ghost.

\section{DISCUSSION}

Since the study was focused only in the grassland and cultivated land, and such grasslands (meadows) are dominant above tree line, herbs appear to be dominant with 196 species i.e. $89.09 \%$; shrubs are represented by 19 species (8.63\%) and climbers 5 species (2.27\%). The ratio of Gymnospermae: Angiospermae was found to be 1:24 at family level, 1:67.5 at genus level and 1:108.5 at species level. This shows that the diversity of gymnosperms in comparison to that of angiosperms in much lower in the study area. Regarding the relative dominance of the families, genera and species, the results obtained from the present study are similar to those of Hara et al. (1978, 1979 \& 1982) and Press et al. (2000).

Manang district lies beyond the Annapurna range, receives very little rainfall. So the region is drier than the rest part of the country. Additionally, area of Upper Manang (Nar-Phoo valley) is separated from the rest parts of the district by Pishang-Kangroo range. Therefore, the rainfall in this area is almost nil and the place is strictly desert in character. The species found in this region are those which can grow in dry habitat in pastureland. Such type of dry and repeatedly disturbed (grazed) habitat is favored by some of the widely distributed taxa like Compositae, Rosaceae, Gentianaceae, Labiatae, Scrophulariaceae, Polygonaceae, Saxifragaceae, Brassicaceae, Umbelliferae, etc. Therefore, the present study has revealed that the area provides suitable habitat for Potentilla, Primula, Saussurea, Saxifraga, Pedicularis, Taraxacum, Ranunculus, Geranium, Gentiana, Bistorta, Aster, etc. On the other hand, most of the weed species found in the cultivated land are found to be common grassland species. This might be due to the management of grassland adjacent to the crop fields. 
A generally considered pattern of species richness along elevation gradient is monotonic decline in the number of species with increasing elevation (Brown, 1988; Stevens, 1992). However, present study reveals a unimodal pattern of species richness, indicating a plateau in species richness between $3500 \mathrm{~m}$ and $4000 \mathrm{masl}$. This finding is consistent with patterns for overall interpolated species richness in the Nepal Himalaya found by Grytnes \& Vetaas (2002), and also with the pattern of plant species richness of inner valley of Manang found by Panthi et al. (2006). There may be several possible reasons for this hump-shaped pattern of species richness along elevation gradient. First, the Neyshang and Nar-Phoo vallies, where the grasslands are located, lie between $3500 \mathrm{~m}$ to $4100 \mathrm{~m}$ altitude, which are comparatively more humid than higher mountains. Second, the grasslands (meadows) start above tree line ecotone (c3800masl); where, as a rule, maximum species richness is encountered. Third, it might be just due to mid-domain effect, because the land masses below $2500 \mathrm{~m}$ and above $5000 \mathrm{~m}$ are separated by hard boundaries and therefore the highest species richness is maintained at midway between those boundaries (Lomolino et al. 2006). Fourth, the grasslands of Upper Manang are subjected for seasonal grazing each year. Such type of medium frequency disturbance leads to prolonged co-existence of species, resulting increase in the species richness (Huston, 1979).

\section{CONCLUSIONS}

Being a semi-arid area and with other harsh climatic conditions, species density and diversity is much lower in the study area than in adjacent lowland areas. Although Upper Manang area is less diverse, species richness between $3500 \mathrm{~m}$ to $4000 \mathrm{~m}$ is quite higher than in adjacent lower and higher elevations. The study area is found to be suitable habitat for some widely distributed, unpalatable and stress tolerant species like Potentilla, Primula, Saussurea, Saxifraga, Pedicularis, Taraxacum, Ranunculus, Geranium, Gentiana, Bistorta, Aster, Artemisia, Draba, Eriophyton, Ephedra, Leontopodium, Anaphalis, Iris, Astragalus, Caragana, etc. which were dominant in the study area. Most of the weed species are common grassland species. This indicates that these stress tolerant grassland species migrate to the cultivated lands and try to settle and compete there with the crop species.

\section{ACKNOWLEDGEMENTS}

We express our sincere thanks to Annapurna Conservation Area Project (ACAP) authorities for providing the permission to carry on the research in the area. Thanks are also due to NUFU ( The Norwegian Council for Higher Education's Program for Development Research and Education, Norway) funded project for granting all financial support for the research work. Finally, we would like to offer heartfelt thanks to the local people of Manang for their knowledge they shared with us and kind cooperation.

\section{REFERERNCES}

Bhattarai, S., Chaudhary, R.P. \& Taylor, R.S.L. 2006. Ethnomedicinal plants used by the people of Manang district, central Nepal. In Journal of Ethnobiology and Ethnomedicine. 2:41.

Brown, J.H. 1988. Species diversity. In: Myers AA and PS Giller (eds), Analytical biogeography: An integrated approach to the study of animal and plant distribution. Chapman and Hall, New York. Pp. 57-89.

Cox, Barry, C. \& Moore, P.D. 2005. Biogeography: An Ecological and Evolutionary Approach. Blackwell Publishing Ltd, Australia. Pp. 46-55.

Forman, L. and Bridson, D. 1989. The Herbarium Handbook. Royal Botanic Gardens, Kew.

Grierson, A.J.C. and Long, D.G. 1983-2001. Flora of Bhutan. Vol. 1, Part 1-3; Vol. 2 Part 1, 2 \& 3, Royal Botanic Garden Edinburgh and Royal Government of Bhutan.

Grytnes, J.A. and Vetaas, O.R. 2002. Species richness and altitude: A comparison between Null models and interpolated plant species richness along the Himalayan altitudinal gradient, Nepal. American Naturalist. 159: 294-304.

Hara, H., Stearn, W.T. and Williams, L.H.J. 1978. An Enumeration of the Flowering Plants of Nepal, Vol. 1. British Museum (Natural History), London.

Hara, H. and Williams, L.H.J.1979. An Enumeration of the Flowering Plants of Nepal, Vol. 2. British Museum (Natural History), London.

Hara, H., Chater, A.O. and Williams, L.H.J. 1982. An Enumeration of the Flowering Plants of Nepal, vol. 3. British Museum (Natural History), London.

Huston, M.A. 1998. Biological Diversity: The coexistence of species on changing landscapes. Cambridge University Press, Cambridge, UK. Pp. 1-7.

Huston, M.A. 1979. A general hypothesis of species diversity. In American Naturalist. 113: 81-101.

Lomolino, M.V., Riddle, B.R. \& Brown, J.H. 2006. Biogeography. Sinauer Associates, Inc. Sunderland, Massachusets. Pp. 622-624.

Noltie, H.J. 1994, 2000. Flora of Bhutan. Vol. 3, Part 1-3. Royal Botanic Garden Edinburgh and Royal Government of Bhutan.

Panthi, M.P., Chaudhary, R.P. \& Vetaas, O.R. 2006. Plant species richness and composition in a trans-Himalayan inner valley of Manang district, central Nepal. In Himalayan Journal of Sciences. 4(6): 12-19.

Pohle, P. 1990. Useful Plants of Manang District: A Contribution to the Ethnobotany of Nepal Himalaya. Frantz Steiner Verlag Wiesbaden GMBH, Stuttgart.

Polunin, O. and Stainton, J.D.A. 1984. Flowers of the Himalaya. Oxford University Press, New Delhi.

Press, J.R., Shrestha, K.K. and Sutton, D.A. 2000. Annotated Checklist of the Flowering Plants of Nepal. The Natural History Museum, London.

Stevens, G.C. 1992. The elevationonal gradient in altitudinal range: an extension of Rapoport's latitudinal rule to altitude. Amerian Naturalis. 140: 893-911.

Zhengyi, W. and Raven, P.H. 1996-2001. Flora of China Vol. 4, 6, 8, 15, 17, 18, 24. Science Press (Beijing) China and Missouri Botanical Garden Press (St. Louis), America. 